will assume the new post on January 1. The MSU-AEC Plant Research Laboratory will be staffed by about eight or nine professors and associate professors and about 90 post-doctoral, pre-doctoral and technical personnel and will bo fully operating by 1967. The over-all emphasis of the Laboratory's programme will be on developmental biology. Dr. Lang is a leading authority on the physiology and biochemistry of plants. He received the doctor of natural science degree at the University of Berlin in 1939.

\section{Chief Alkali Inspector for England and Wales:}

\section{Dr. J. S. Carter, C.B.E.}

DR. J. S. CARTER, chief alkali inspector for England and Wales for the past nine years, is to retire on November 30 at the age of sixty-four. $\mathrm{H}_{\theta}$ will be succoeded by Mr. F. E. Ireland, who is at present a deputy chief inspector. Dr. Carter was born at Leeds. Ho obtained a first-class honours degree and a Ph D. in chemistry at the University of Leeds. He began his career in the public service in the Laboratory of the Govornment Chemist, before becoming assistant to the chief alkali inspector in 1928. In 1933 he was appointed alkali inspector for the London area. During the War, Dr. Carter was seconded to the Ministry of Supply, and became deputy controller of chemicals. Shortly after his return to the Inspectorate he was promoted to deputy chief inspector in 1946, and in 1955 he succeeded Mr. W. A. Damon as chief inspector. The scope of the work of the Alkali Inspectorate is evident in its one hundredth annual report, issued this year (Nature, 203, 1027; 1964).

\section{Earth and Planetary Science in the Graduate Research Centre of the South-west, Dallas: \\ Prof. Francis S. Johnson}

Prof. Francis S. Johnson has been appointed as director of the Earth and Planetary Sciences Laboratory of the Graduate Research Centre of the South-west, Dallas. Prof. Johnson, who joined the Centre as head of the Division of Atmospheric and Space Sciences in March 1962, was formerly head of Space Physics Research at Lockheed Missiles and Spacecraft Co., Palo Alto, California. Prof. Johnson was born in Omak, Washington, and educated in the United States and Canada. He was awarded a Ph.D. in physies from the University of California at Los Angeles in 1958. The Earth and Planetary Sciences Laboratory comprises the Divisions of Geosciences, Mathematics and Mathematical Physics, and Atmospheric and Space Sciences. Research projects now being carried out by the Space Sciences Division are aimed at an understanding of planotary atmospheres and interplanetary space, including magnetic fields, highenergy particles, and the outer atmosphere of the Sun. In the Geosciences Division, vigorous group research programmes are being pursued in the fields of seismology, marine geophysies, gravity, geomagnetism, palæomagnetism, geochronology, heat flow measurements, and investigations of the Moon. In the Mathematies and Mathematical Physics Division, where a strong group in both mathematics and theoretical physics has been brought together, research is being done in relativity theory.

\section{Day-release Courses}

A sHort debate in the House of Commons on day. release for further education, on July 29 , was opened by Mr. J. Boyd $\rightarrow n$, and in replying the joint under-secretary for education and science, Mr. C. Chataway, said that present expenditure on further education by local education authorities had risen from nearly $£ 29$ million in $1955-56$ to more than $£ 80$ million in $1962-63$, and capital expenditure from $£ 8,487,000$ to $£ 26,018,000$. The number of full-time students in grant-aided institutions had risen from 56,500 to 140,700 , with large increases also in the number of sandwich and part-time day students. He agreed that the failure-rates for national certificates and diplomas were disturbing, but was confident that these could be reduced by improving the selection of students for courses, and by the steady and continuing improvement of opportunities for transfer when a course, for one reason or another, proved unsuitable to a particular student. Further, by the implementation of the Industrial Training Act, industrial training and further education would be moro elosely associated in the future, as recommended by the industrial training boards. Mr. Chataway said that the Government believed it would be possible to achieve the additional 250,000 day-release places recommended for young people under eighteen by the Henniker-Heaton Committee without any general compulsion. Any attempt to move nearer to compulsory day-release for all could only be at the expense of more urgent educational projects, and this the Minister was not prepared to envisage. The Government preferred to accept the order of priorities recommended by the Henniker-Heaton Committee: first, priority for young people who are being trained in occupations requiring knowledge and skills with which courses of further education are associated; secondly, a specific attempt to provide day-release opportunities for boys and girls who have shown themselves anxious to take advantage of further education facilities by pursuing evening vocational courses; and thirdly, provision of day-release opportunities for boys and girls wishing to pursue non-vocational courses, and who in their work receive little educational training.

\section{The Australian Museum, Sydney}

Australian Natural History, published quarterly by the Australian Museum, Sydney, always contains articles of popular as well as specialized interest. The current issue (14, No. 10; June 15, 1964) includes articles on searching for meteorites, territorial areas in rabbit populations, and the funeral rites of the Ngadju Dyaks of Central Borneo.

\section{New Ulster Folk Museum}

ON July 2 the Governor of Northern Ireland, Lord Wakehurst, opened the introductory exhibition of the New Ulster Folk Museum. This comprises a systematic layout of selected specimens from the collection and, in addition, two buildings - a nineteenth-century waterpowered spade mill from Co. Tyrone and an eighteenthcentury cottier's house from Co. Londonderry - have been re-erected. On the farm belonging to Cultra Manor is an exhibition of early farm vehicles and implements.

\section{Journal of Algebra}

ALGEBRA is not merely a study in itself, it is a language in which much of mathematics must be expressed; developments come not only from within but also from the prossures and demands of almost every other branch of mathematics. The importance of this central position justifies and perhaps demands a periodical devoted to research papers in the field of algebra, and in related fields in which algebraic applications play a prominent part. The new Journal of Algebra is a quarterly, published by the Academic Press (New York and London), with an annual subscription of 8 dollars. The editor-in-chief is Prof. Graham Higman (Oxford), who has the assistance of a strong editorial board, drawn mainly from the United States and Britain, with representatives from France, Germany and Italy. The first number, containing nine items, appeared in April 1964.

\section{A Japanese Journal of Nuclear Science}

Since 1959 the Atomic Energy Society of Japan has published the monthly journal Nihon-Genshiryoku-Gakkai Shi (Journal of the Atomic Energy Society of Japan), and it is now in its sixth volume. However, since this journal is written mostly in Japanese, its contents have had limited readership and recognition. The Society has therefore decided to publish a new monthly journal, with 